
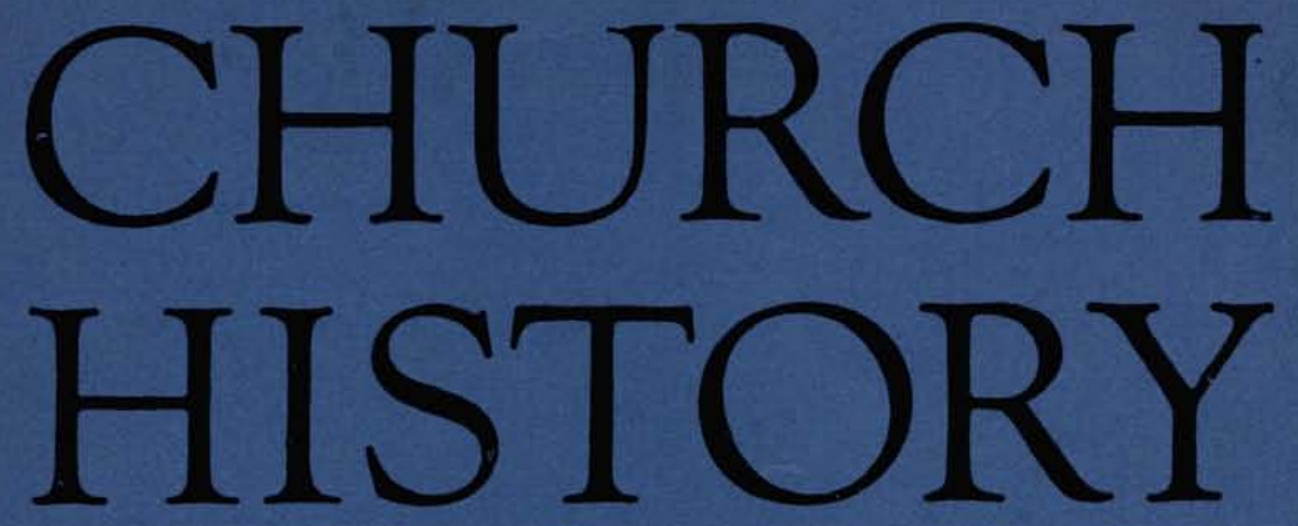

SEPTEMBER, 1965

Theodosius' Horse: Reflections on the Predicament of the Church Historian Albert C. Outler

The Earliest Text of the Old Roman Symbol:A Debate with Hans Lietzmann and J.N.D. Kelly D. Larrimore Holland

Three Medieval Chroniclers: Monastic Historiography and Biblical Eschatology in Hugh of St. Victor, Otto of Freising, and Ordericus Vitalis Ray C. Petry An Episcopal Petition from the Province of Rouen, 1281

Richard Kay

Thomas Muntzer in Marxist Thought Abraham Friesen The Puritan Notion of the Covenant in Jonathan Edwards' Doctrine of Faith C. Conrad Cherry Comprehension in the Later Seventeenth Century: A Postscript

H. G. Horwitz

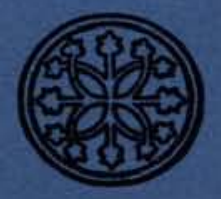

Published by

THE AMERICAN SOCIETY OF CHURCH HISTORY 
Founded By PhIIIP Schaff, 1888: Reorganized, 1906; Incorporated BX ACT OF THE Legtsl.ATURe OF NeW YoRK, 1916

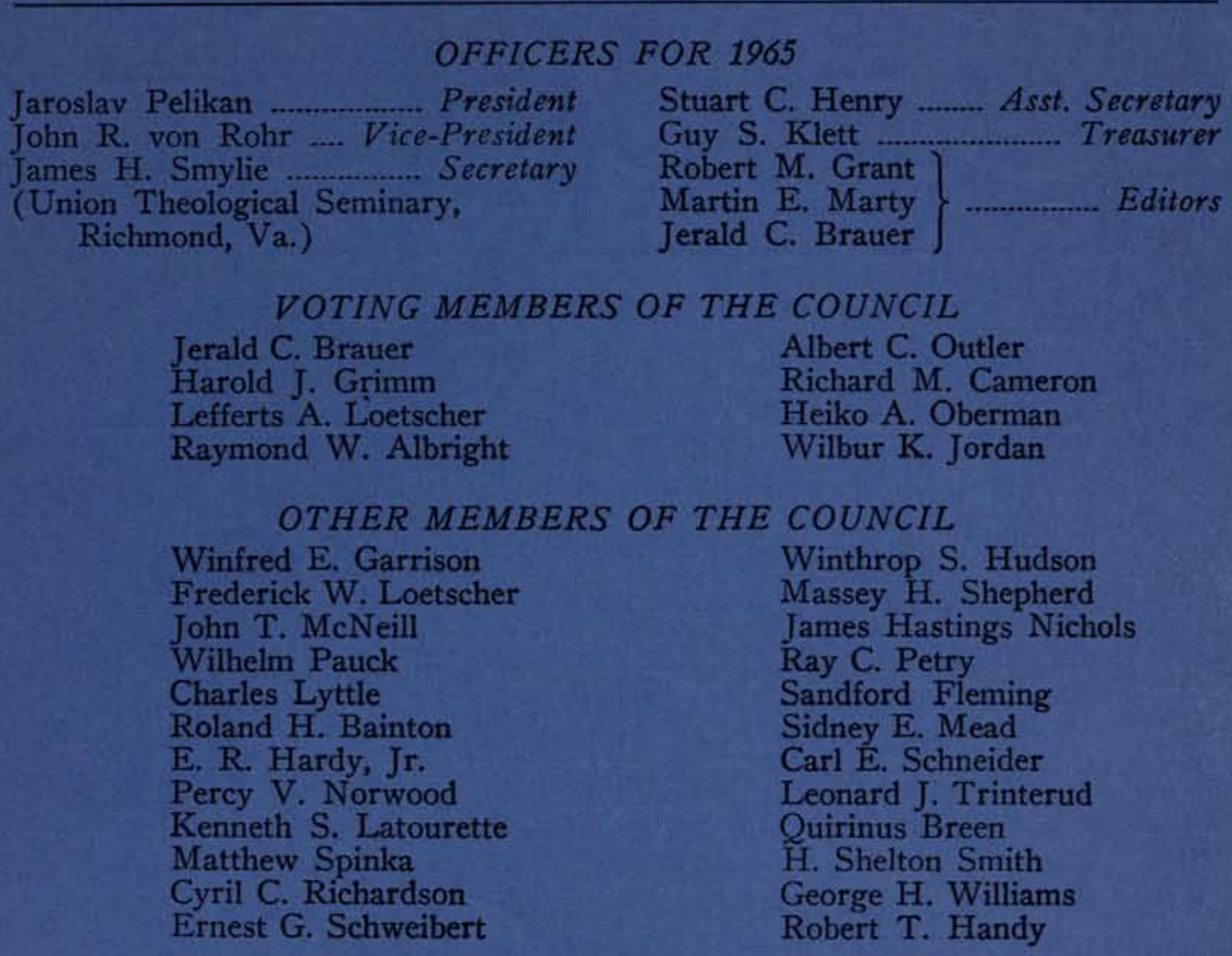

Subscription prices are five dollars a year, one dollar and a half for single copies. Twenty-five cents a year should be added for foreign countries. Remittances should be made to the order of the American Society of Church History. Subscriptions, renewals, changes of address, claims for missing numbers, orders for single copies of current or back issues should be addressed to Guy S. Klett, 321 Mill Road, Oreland, Pennsylvania. Claims for missing numbers will be honored without charge if made within two months following the regular month of publication.

Manuscripts and books for review should be sent to the editorial office, Swift Hall, University of Chicago, Chicago 37, Illinois.

Microfilm reproductions of the American Society of Church History Papers, series one and two, and of Church History, volumes I-XVII (1932-1948) are available at cost ( $\$ 22$ and $\$ 39$, respectively, plus transportation) from the ATLA Board of Microtext. Orders should be sent to Raymond P. Morris, Library of the Yale Divinity School, 409 Prospect Street, New Haven 11, Connecticut, as well as inquiries as to microfilm portions, Xerox copies.

Microfilm reproductions of Church History beginning with Volume XVIII are available to subscribers and to members of the Society from University Microfilms, 313 North First Street, Ann Arbor, Michigan.

A cumulative Index of both series of Papers and of Church History through volume XXX (1961) is available at two dollars a copy from Guy S. Klett, 321 Mill Road, Oreland, Pennsylvania.

Publication office is Berne, Indiana 46711

Second-class postage paid at Berne, Indiana 46711.

Send change of address and Forms 3579 to 321 Mill Road, Oreland, Pennsylvania 19075 . 


\section{GHURGH HISTORY}

Edited by

Robert M. Grant, Martin E. Marty, Jerald C. Brauer with the cooperation of

R. Pierce Beaver (Divinity School, University of Chicago)

RoBert T. HANDy (Union Theological Seminary)

E. R. HARDY, JR. (Berkeley Divinity School)

Winthrop S. Hudson (ColgateRochester Divinity School)
James H. Nichols (Princeton Theological Seminary)

Jaroslav Pelikan (Divinity School, Yale University)

Ray C. Petry (Divinity School, Duke University)

LeONARd J; Trinterud (San Francisco Theological Seminary)

George H. Williams (Divinity School, Harvard University)

\begin{tabular}{lll} 
VOL. XXXIV SEPTEMBER, 1965 & No. 3 \\
\hline
\end{tabular}

\section{TABLE OF CONTENTS}

Theodosius' Horse: Reflections on the Predicament of the Church Historian

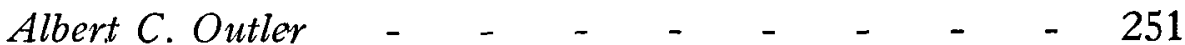

The Earliest Text of the Old Roman Symbol: A Debate

with Hans Leitzmann and J. N. D. Kelly

D. Larrimore Holland - $\quad$ - $\quad$ - $\quad$ - $\quad$ - $\quad$ - 262

Three Medieval Chroniclers: Monastic Historiography

and Biblical Eschatology in Hugh of St. Victor, Otto of Freising, and Ordericus Vitalis

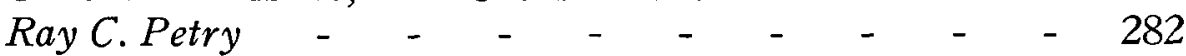

An Episcopal Petition from the Province of Rouen, 1281

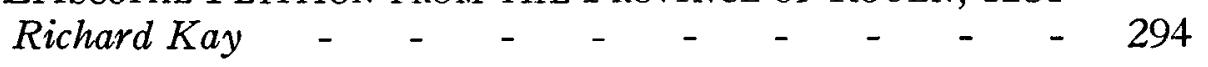

Thomas Muntzer in Marxist Thought

Abraham Friesen - $\quad$ - $\quad$ - $\quad$ - $\quad$ - $\quad$ - $\quad$ - $\quad$ - 306

The Puritan Notion of the Covenant in Jonathan

EDWARDS' DOCTRINE OF FAITH

C. Conrad Cherry - $\quad$ - $\quad$ - $\quad$ - $\quad$ - $\quad$ - $\quad$ - $\quad$ - 328

Comprehension in the Later Seventeenth Century:

A POSTSCRIPT

H. G. Horwitz 


\section{CONTENTS}

Doctoral Dissertations

Ezekiel Cooper, 1763-1847; An Early American Methodist

LEADER

Lester Buryl Scherer

History of Negotiations for Union Between Methodists AND Non-Methodists in the UNited States Paul Freeman Blankenship

The Religious Thought of Gardiner Spring .... William Russell Hoyt, III Book Reviews - $\quad$ - $\quad$ - $\quad$ - $\quad$ - $\quad$ - $\quad$ - $\quad$ - $\quad$ - 352

Buckley, Francis J.: Christ and the Church according to Gregory of Elvira E. R. Hardy

Benko, Stephen: The Meaning of Sanctorum Communio F. Ernest Stoeffler

TAylor, F. M. and TAylor, JoAN : Anglo-Saxon Architecture Richard Luman

Dunlop, Annie I. (Ed.): Acta Facultatis Artium Universitatis Sanctiandree 1413-1588 John T. McNeill

Pelikan, Jaroslav: Obedient Rebels B. A. Gerrish

Aubert Hippolyte (Ed.) : Correspondance de Théodore de Bèze, Tome III Paul Minus

Clebsch, William A.: England's Earliest Protestants, $1520-1535$

John T. McNeill

LOomie, Albert J.: The Spanish Elizabethans De Lamar Jensen DE GuIBERT, JoSEPH : The Jesuits: Their Spiritual Doctrine and Practice Albert J. Loomie

Cragg, Gerald R.: The Church and The Age of Reason, 1648-1789

B. A. Gerrish

Simon, Paul: Lovejoy, Martyr to Freedom Edwin S. Gaustad

Conzemius, Victor (Ed.) : Ignaz von Döllinger Briefwechsel mit Lord Acton, Band I

J. H. Nichols

Meyer, CarL S. (Ed.) : Moving Frontiers. Readings in the History of the Lutheran Church-Missouri Synod ........ E. Theodore Bachmann

Stevenson, Dwight E.: Lexington Theological Seminary, 1865-1965 Winfred E. Garrison

Bea, Augustin Cardinal: Unity in Freedom; Reflections on the Human Family Albert C. Outler

Gardner-Smith, P. (Ed.) : The Roads Converge .. Massey H. Shepherd, Jr. Beaver, R. Pierce : Envoys of Peace Cornelius J. Dyck

Washington, Joseph R., JR.: Black Religion Elmer G. Million

Book Notes

Minutes of the Council 